\title{
Social science perspectives on drivers of and responses to global climate change
}

\author{
Andrew K. Jorgenson ${ }^{1}$ | Shirley Fiske ${ }^{2}$ | Klaus Hubacek ${ }^{3}$ | ${\text { Jia } \text { Li }^{4} \text { | Tom McGovern }}^{5}$ | \\ Torben Rick ${ }^{6}$ | Juliet B. Schor ${ }^{1}$ | William Solecki ${ }^{7}$ | Richard York ${ }^{8}$ | Ariela Zycherman ${ }^{9}$
}

${ }^{1}$ Department of Sociology, Boston College, Chestnut Hill, Massachusetts

${ }^{2}$ Department of Anthropology, University of Maryland, College Park, Maryland

${ }^{3}$ Department of Geographical Sciences, University of Maryland, College Park, Maryland

${ }^{4}$ U.S. Environmental Protection Agency,

Washington, DC

${ }^{5}$ Department of Anthropology, Hunter College-CUNY, New York, New York

${ }^{6}$ Department of Anthropology, National Museum of Natural History, Smithsonian Institution,

Washington, DC

${ }^{7}$ Department of Geography, Hunter

College-CUNY, New York, New York

${ }^{8}$ Department of Sociology, University of Oregon,

Eugene, Oregon

${ }^{9}$ USDA-National Institute of Food and

Agriculture, Washington, DC

Correspondence

Andrew K. Jorgenson, Department of Sociology, Boston College, Chestnut Hill, MA 02467.

Email: jorgenan@bc.edu

Funding information

National Aeronautics and Space Administration, Grant number NNX17AG17G; U.S. Bureau of Land Management; American Anthropological

Association; American Association of

Geographers; American Sociological Association; Society for American Archaeology

Edited by Stéphane Hallegatte, Domain Editor, and Mike Hulme, Editor-in-Chief
This article provides a review of recent anthropological, archeological, geographi$\mathrm{cal}$, and sociological research on anthropogenic drivers of climate change, with a particular focus on drivers of carbon emissions, mitigation and adaptation. The four disciplines emphasize cultural, economic, geographic, historical, political, and social-structural factors to be important drivers of and responses to climate change. Each of these disciplines has unique perspectives and makes noteworthy contributions to our shared understanding of anthropogenic drivers, but they also complement one another and contribute to integrated, multidisciplinary frameworks. The article begins with discussions of research on temporal dimensions of human drivers of carbon emissions, highlighting interactions between long-term and nearterm drivers. Next, descriptions of the disciplines' contributions to the understanding of mitigation and adaptation are provided. It concludes with a summary of key lessons offered by the four disciplines as well as suggestions for future research.

This article is categorized under:

Climate Economics > Economics and Climate Change

\section{KEYWORDS}

adaptation, anthropology, archeology, climate change, geography, greenhouse gas emissions, mitigation, social science, sociology, sustainability

\section{1 | INTRODUCTION}

The drivers of climate change are explored in a wide range of scientific and climate assessment literatures. "Anthropogenic" drivers refer to the human actions that cause climate change and the societal factors that shape and condition those actions (Rosa \& Dietz, 2012). More broadly, human driving forces, in this context, are the range of characteristics of societies that have substantial influence on the global climate (Dietz, Rosa, \& York, 2010; Rosa, Rudel, York, Jorgenson, \& Dietz, 2015).

This is an open access article under the terms of the Creative Commons Attribution License, which permits use, distribution and reproduction in any medium, provided the original work is properly cited. 
Emissions and atmospheric concentrations of long-lived greenhouse gases (GHG), especially carbon emissions, have increased dramatically since the pre-industrial period. That increase is due primarily to human activities associated with fossilfuel use and agriculture, while other land-use changes, such as deforestation, provide significant but smaller contributions (IPCC, 2007, 2014a; USGCRP, 2017). The scale of these emissions has been an important component in the designation of a new geological era in which human activity is a primary driver-the Anthropocene.

This article reviews recent anthropological, archeological, geographical, and sociological perspectives on anthropogenic drivers of climate change, with a particular focus on drivers of carbon emissions. Attention is also given to some of the ways in which these social science disciplines contribute to research on mitigation and adaptation. As a whole, the four disciplines emphasize cultural, economic, geographic, historical, political, and social-structural factors to be important drivers of and responses to climate change. While each of these disciplines has unique perspectives and makes noteworthy contributions to our shared understanding of the human dimensions of climate change, they also complement one another and contribute to integrated, multidisciplinary frameworks (Dietz, Sovacool, \& Stern, 2016; Stern, Sovacool, \& Dietz, 2016).

While far from an exhaustive review of what the four disciplines have to offer, the article covers important contributions from these disciplines that inform knowledge of drivers and responses to climate change. It begins with discussions of temporal dimensions, identifying and presenting interactions between long-term and near-term human drivers of carbon emissions. Next, descriptions of the disciplines' contributions to the understanding of mitigation and adaptation are provided. The conclusion includes a summary of key lessons offered by the four disciplines as well as suggestions for future research.

\section{2 | DRIVERS AND THEIR INTERACTIONS OVER TIME}

The long-term and near-term drivers of climate change continuously interact (Dietz, 2017). Among the anthropogenic drivers of carbon emissions that anthropology, archeology, geography, and sociology investigate are economic systems, including growth, cycles, consumption, and trade; power, social stratification, and inequality; population growth and demographic shifts; technology; infrastructure; and land-use change and land transformation. "Long" and "near" terms are often defined differently within and between disciplines. "Long-term" may be applied to several decades, one or more centuries, or even longer periods, while "near-term" may refer to a period shorter than a year.

\subsection{Social dimensions of economic systems}

This section focuses on the economic activities and trends that lead to increased carbon emissions. Section 2.1.1 considers the relationships between national economic growth and local-level processes, and the impacts these factors have on emissions. Section 2.1.2 focuses primarily on the broader impacts of collective and individual economic practices, and also provides a brief summary of recent research on nations' militaries.

\subsection{1 | Economic growth and cycles}

One of the major drivers of climate change is economic growth, which includes long-term and near-term factors that influence the timing and extent of the driver's impact. Sociological research has employed longitudinal modeling techniques and statistical interactions to assess the potentially changing effect of economic development on national-level carbon emissions (Jorgenson \& Clark, 2012; Knight \& Schor, 2014; Longhofer \& Jorgenson, 2017; Thombs, 2018a). This body of research provides a sociological approach to analyses of a potential decoupling of gross domestic product (GDP) and emissions (OECD, 2002), and commonly focuses on testing hypotheses derived from social theories, particularly ecological modernization theory and treadmill of production theory.

Briefly, ecological modernization theory suggests that processes of modernization result in added reflexivity throughout the socioeconomic system (Mol, 2003; Mol, Spaargaren, \& Sonnenfeld, 2014). Technological development and environmental consciousness, both of which go hand-in-hand with economic development, are seen as key components of modernization via the greening of industrial production processes, including reduced fossil fuel consumption, while also leading to more sustainable forms of consumption. In contrast, treadmill of production theory argues that since market economies are predicated on increasing profits through expansion, energy consumption and forms of pollution continually expand while overall environmental conditions deteriorate (Gould, Pellow, \& Schnaiberg, 2008; Schnaiberg, 1980). Thus, economic development involves increases in resource use and waste generated from the various stages in production processes, including increased fossil fuel consumption and resultant carbon emissions.

In the first study in sociology that takes such an approach, Jorgenson and Clark (2012) use interactions between GDP per capita and time in longitudinal models of anthropogenic carbon emissions for samples of developed and developing countries covering the 1960-2005 period. Three measures of national carbon emissions are analyzed: total emissions, per capita 
emissions, and emissions per unit of GDP. The results indicate a strong relationship between per capita emissions and GDP per capita in developed nations that is stable in magnitude through time. For developing countries they find that the association between emissions and GDP per capita increases in magnitude through time, the opposite of decoupling, but still remains smaller in magnitude than the relationship between per capita emissions and GDP in developed countries. For total emissions, the estimated effect of GDP per capita decreased in magnitude over time in developed countries, providing some evidence of a decoupling for such nations, while for developing countries the results indicate a stable effect of GDP per capita on total emissions through time. The analysis of emissions per unit of GDP suggests a slight decoupling for the sample of developed nations, while the findings for the sample of developing countries are inconclusive. In a more recent longitudinal study that extends the temporal scope of the analysis to 2010, Thombs (2018a) replicates the findings of Jorgenson and Clark (2012) across all three measures of emissions. Overall, this body of research on decoupling provides mixed support for ecological modernization theory and treadmill of production theory, and suggests that both frameworks could benefit from further consideration of how the global organization of production and the structure of international trade influence the relationship between carbon emissions and economic development.

Similar modeling techniques that include interactions between time and measures of GDP per capita have been used in studies of the effect of economic growth on the "carbon intensity of human well-being" (CIWB)—a ratio between per capita carbon emissions and a measure of human well-being-for samples of nations in the Americas, Europe, Oceania, Asia, and Africa (Jorgenson, 2014). Findings suggest that the effect of GDP per capita on CIWB is relatively large, positive, and stable in magnitude through time for nations in North America, Europe, and Oceania, and has increased in magnitude through time for nations in the other regional samples (Jorgenson, 2014; see also Dietz, 2015; Dietz, Rosa, \& York, 2009, Dietz, Rosa, \& York, 2012; Mayer, 2017; Mazur \& Rosa, 1974).

Recent sociological analyses of national carbon emissions have also highlighted notable temporal differences in the effects of urbanization across regions, which is tightly connected to processes of economic growth (Jorgenson, Auerbach, \& Clark, 2014). For nations in Asia, the estimated effect of urbanization (measured as the percent of the nation's population residing in urban areas) on emissions has increased in magnitude through time, while for nations in Latin America, the estimated effect of urbanization has fluctuated slightly through time, but continues to be moderate in magnitude. For the wealthier nations in North America, Europe, and Oceania, the effect of urbanization on emissions is larger than for nations in other regions, but gradually decreased in the 1980s and 1990s, followed by a moderate increase in the early 2000s. Related research shows that in developing nations with a larger urban slum prevalence, the overall effect of urbanization on carbon emissions is suppressed to some extent, given that households in urban slums are structurally disadvantaged and generally consume less fossil fuel energy and other carbon-intensive goods (Givens, 2015; Jorgenson, Rice, \& Clark, 2010; McGee, Ergas, Greiner, \& Clement, 2017), which highlights socioeconomic heterogeneity and structural inequities within urban contexts (Elliott \& Clement, 2014).

Drivers that show the most noticeable effects over short periods can demonstrate how economic cycles increase or decrease emissions. In the United States, for example, carbon emissions from the burning of fossil fuels declined between 2007 and 2013. According to research by geographers, the economic recession was more important than the substitution of natural gas for coal in the power sector for explaining the decline (Feng, Davis, Sun, \& Hubacek, 2015). Relevant factors were a reduction in overall economic activity, changes in the production of industrial goods because private sector enterprises were less willing to invest in capital formation, and a moderate increase in the use of renewable energy relative to fossil fuel energy (Feng, Davis, Sun, \& Hubacek, 2016). Historically, technical progress has only partially compensated for additional emissions from economic growth in both national and international contexts (Jackson et al., 2016; Peters, Weber, Guan, \& Hubacek, 2007; Yao, Feng, \& Hubacek, 2015).

The collapse of the Soviet Union also led to declines in GHG emissions. During the 1990s, the former Soviet republics experienced demographic and economic decline along with de-urbanization, all of which influenced carbon emissions. Studying these trends, York (2008), a sociologist, finds not only that those reversals led to reductions in carbon emissions but also that the events in the former Soviet republics provided a clear example of dramatic carbon emissions reductions. The related infrastructural momentum (the energy capacity and demand stemming from durable infrastructure like roads, pipelines, and factories, that persist even in economic downturns), however, meant that former Soviet republics still had higher emissions than other low to moderate income nations that had not industrialized so intensively (York, 2008).

Although the economic collapse in former Soviet republics obviously does not present a desirable model to reduce emissions, the Soviet example shows that once energy intensive infrastructure is in place, it generates some degree of energy consumption that is hard to suppress. Subsequent research in sociology has established a general pattern across nations where economic decline does not reduce carbon emissions and energy use as much as economic growth spurs them, which once again highlights the degree to which energy demand can be difficult to curtail once industrial infrastructure has been developed (York, 2012a; York \& Light, 2017). 
Sociologists have also analyzed differences in how components of GDP contribute to emissions. For example, a series of cross-sectional (Schor, 2005) and longitudinal studies (Fitzgerald, Jorgenson, \& Clark, 2015; Fitzgerald, Schor, \& Jorgenson, 2018; Knight, Rosa, \& Schor, 2013) show that working hours are strongly associated with carbon emissions, whether considering just developed countries, both developing and developed countries, or within the United States, across states. The strongest relationship is what has been called the "scale effect:" the number of hours worked is associated with the size of aggregate output. Countries that have reduced average hours, such as Northern European countries, are lower emitters, ceteris paribus. The second, smaller channel of influence, (the "composition effect") occurs via household decision-making: holding income constant, households with less free time engage in more carbon-intensive consumption. This hypothesized effect has not been measured directly, but is evident in economy-wide analyses.

\subsection{2 | Consumption}

As consumption is frequently the largest component of output, social scientists have studied its role in GHG emissions. Thus, the rise of consumer society or consumer culture, in which human beings increasingly practice a consumer-oriented way of life, can be understood as a driver of emissions (Baudrillard, 2017). Income, infrastructure, social organization, and culture all affect expenditure patterns and investment and in turn have direct effects on climate change. Higher income and wealth generally lead to higher energy consumption and carbon emissions. And according to research in geography, the urbanization of populations, particularly in low and moderate income settings, is also associated with the development of high resourceconsuming lifestyles (Leichenko \& Solecki, 2005).

Carbon disparity across nations changes with increasing income. Research in geography by Hubacek et al. (2017a) shows that when countries are ranked from lowest to highest income, substantial variation becomes evident among lower-income countries: there is a declining disparity of carbon footprints within a country as income increases. The disparity in carbon footprints declines as countries become richer, but the average carbon footprint increases along with income. They also find for all countries that the carbon footprint grows with increasing income even though carbon intensity tends to decline, that is, more lower carbon consumption expenditures (such as a larger share of healthcare or education) are added into the consumption mix as income rises.

Anthropologically and sociologically, understanding consumption as a driver takes into account cultural and social contexts (Dietz, Stern, \& Weber, 2013), such as through examining status consumption and status competition (EhrhardtMartinez \& Schor, 2015; Wilk, 2010). Status seeking contributes to emissions as it leads people to purchase carbon-intensive consumer goods and services, such as large homes, large vehicles, frequent vacations, and other luxuries, which have tended to serve as status markers on account of their social visibility (Schor, 1998). Consumption patterns are also capable of helping to reduce emissions, however, when green products such as hybrid vehicles or solar roof installations become high-status indicators (Griskevicus, Tybur, \& Van Den Bergh, 2010).

Consumer practices are important as well. An increase in energy-intensive practices, such as greater use of heating and cooling or a shift to daily showering, tends to increase emissions, but modifying these practices or adopting others, such as choosing public transportation over driving, can reduce emissions (Dietz, Gardner, Gilligan, Stern, \& Vandenbergh, 2009; Ehrhardt-Martinez \& Schor, 2015; Shove, Pantzar, \& Watson, 2012). Choosing green energy options, such as rooftop solar photovoltaic systems, has been shown to have a strong spatial pattern of adoption leading to the conclusion that "peer effects" can be a strong force in consumer choices. Adoption often occurs among neighboring residences, irrespective of economic class and political party (Graziano \& Gillingham, 2015).

The "lifestyle" concept is also useful in analyzing carbon emissions. The ways in which people live and consume are reflected in the consumption patterns of societal groups with different socioeconomic characteristics, such as identity, education, employment, or family status (Baiocchi, Minx, \& Hubacek, 2010). Housing is one significant aspect of lifestylerelated choices (Huddart Kennedy, Krahn, \& Krogman, 2014). Suburbanites, especially in more affluent nations, generally purchase large, capacious homes with substantial heating and cooling requirements. Commuting distance and access to public transportation, recreation areas, city centers, public services, and shops are other important neighborhood-specific, lifestyle-associated determinants of carbon emissions (Baiocchi et al., 2010). Drivers for different lifestyle groups have been assessed by geographers at fine spatial scales using big data (Hubacek et al., 2016). Geo-demographics uses a large set of spatially specific variables of characteristics that account for household context as it contributes to emission patterns. The key determinants of lifestyle-related emissions, as identified through this type of analysis, could also impede change and emissions reduction.

A growing area of environmental social science research on consumption focuses instead on nations' militaries. For example, recent longitudinal analyses within sociology link higher levels of national-level energy consumption and carbon emissions to the relative size (measured as military participation rate) and capital intensity (measured as military expenditures as \% GDP and military expenditures per soldier) of nation's militaries, a finding which holds for both developed and developing 
nations (Bradford \& Stoner, 2017; Clark, Jorgenson, \& Kentor, 2010; Jorgenson, Clark, \& Kentor, 2010). A network of military bases encompasses the globe, requiring the consumption of a vast amount of resources—including fossil fuels—to staff, operate, and transport equipment and personnel between destinations (Gould, 2007; Hooks and Smith 2004, 2005, 2012). Common military equipment, such as planes, ships, helicopters, tanks, and vehicles requires the consumption of large amounts of energy. For example, $1 \mathrm{hr}$ of operation of a nonnuclear aircraft carrier consumes 21,300 L (over 5,621 gal) of fossil fuel; large, high-tech military helicopters burn five gallons of fuel for every mile that they travel; and fighter planes, such as the F-15 and F-16, consume between 1,500 and 1,700 gal of fuel per hour. If their afterburners are used, up to 14,400 gal are exhausted per hour (Clark \& Jorgenson, 2012). This body of research on the environmental impacts of nations' militaries is also relevant for approaches to international inequality and ecologically unequal exchange, which are discussed below.

\section{2 | Power, social stratification, and inequality}

Interactions among power, social stratification, and inequality—whether international, regional, national, or subnational—all affect emissions and climate change. Along with the United States, the highest-emission nations include China, India, and Brazil. Who wields power in those nations? The answer to that question has national and international policy implications that not only affect global changes but also influences how local populations experience and contribute to growth in carbon emissions and climate change.

Theoretical perspectives from social science that address questions of power and inequality include political economy and political ecology, as well as ideas about state action and individual choice and behavior. Research in geography and sociology indicates that recent decades have seen increased global outsourcing, through manufacturing or extraction, of pollution from wealthier countries to poorer ones (Jorgenson, 2007; Jorgenson, Dick, \& Mahutga, 2007; Prell \& Feng, 2016) and among regions within a nation (Collins, Munoz, \& JaJa, 2016; Feng et al., 2013; Williams, 2001). Poor regions often provide inputs and labor for global production networks, and are the locations of the stages of energy-intensive production that contribute heavily to pollution, including carbon emissions from the burning of fossil fuels (Feng et al., 2013; Grimes \& Kentor, 2003; Prell, Feng, Sun, Geores, \& Hubacek, 2014).

In terms of benefits and costs along global supply chains, the current structure of those chains tends to reify international inequalities in the world system (Chase-Dunn \& Grimes, 1995). Larger shares of value added, in comparison to shares of pollution, are generally prompted within more-developed countries, while less-developed countries experience more environmental destruction and associated health impacts per unit of value added for their contribution to global supply chains (Burns, Davis, \& Kick, 1997; Greiner \& McGee, 2018; Prell et al., 2014; Prell \& Feng, 2016). While China, as of this writing, is experiencing the greatest negative effects, other nations and regions play similar roles. Bangladesh, Cambodia, and India are leading producers of textiles, and Laos, Myanmar, and several nations in Africa have many sites of "land grabs," the buying or leasing of land for export production on terms unfavorable to local people, with consequences for the environment and climate change, including deforestation (Marselis, Feng, Liu, Teodoro, \& Hubacek, 2017).

Global inequalities can also be considered from the perspective of households, rather than nations. Globally, households with incomes in the top $10 \%$ are responsible for $36 \%$ of carbon emissions, while those in the bottom 50\% are responsible for only $15 \%$ of emissions. The average annual carbon footprint of global elites is about 14 times that of the lowest income group. In 2010, these footprints ranged from 26.3 tons for the highest global income category to 1.9 tons for the lowest (Hubacek et al., 2017b).

Recent studies in sociology and geography have looked at domestic inequality as a driver of emissions, finding that domestic inequality of both income and wealth are positively associated with carbon emissions, especially via concentration of income and wealth at the top of the distribution. These associations are observed within more economically developed nations, such as the United States (Jorgenson, Schor, \& Huang, 2017; Jorgenson, Schor, Knight, \& Huang, 2016; Knight, Schor, \& Jorgenson, 2017) and in developing nations as well (Hubacek et al., 2017a).

A number of factors account for the positive associations between emissions and income inequality and wealth inequality. Higher-income and wealthier groups tend to consume more goods and services as they engage in Veblenian statusconsumption (Veblen, 1934) or consumption competition (Schor, 1998). These dynamics lead households to increase their spending to keep up with the visible lifestyles of higher-income, wealthier households, which in recent decades has entailed consumption of energy-intensive luxuries such as multiple homes and private planes. The wealthy are also owners of polluting firms and energy producing enterprises. To protect these assets, they are more likely to use their economic resources to gain political power, which they use to dominate the policy environment (Downey, 2015; Jorgenson, Schor, \& Huang, 2017; Knight et al., 2017; Prell, Sun, Feng, \& Myroniuk, 2015). An additional pathway is that income inequality has been shown to have a positive association with working hours (Bowles \& Park, 2005), and recent sociological research, reviewed above, has shown that increased working hours are drivers of energy consumption and carbon emissions (e.g., Fitzgerald et al., 2018; Knight et al., 2013). 
Another important aspect of inequality related to emissions is ecologically unequal exchange, a perspective that cuts across multiple social science disciplines, including anthropology, geography, and sociology. Unequal international exchange is the assertion of asymmetrical power relationships between more-developed and less-developed countries, as the former gain disproportionate advantages at the expense of the latter through trade patterns and global production networks. Ecologically unequal exchange refers to the environmentally damaging removal of energy and other natural-resource assets from and the externalization of environmentally damaging production and disposal activities to less-developed countries. Research in this tradition indicates that asymmetrical trade relationships and global production network characteristics contribute to the growth of energy use, production-based carbon emissions and deforestation within developing nations (Bunker, 1984; Feng, Hubacek, \& Yu, 2014; Givens, 2018; Hornborg \& Martinez-Alier, 2016; Huang, 2018; Jorgenson, 2006, 2012; Prell et al., 2015; Roberts \& Parks, 2007). In a related vein, research on the environmental impacts of militarization (e.g., Bradford \& Stoner, 2017; Clark et al., 2010), which is discussed in greater detail above, suggests that nations with larger and more technologically advanced militaries are more able to secure and maintain access to greater amounts of fossil fuels and other natural resources from different regions of the world, further leading to increased carbon emissions (Kentor, 2000; Tilly, 1992).

\section{3 | Demographic factors}

The size and growth of the human population are well established as major drivers of environmental change, including carbon emissions, and much social science research provides empirical evidence supporting these claims (Burns et al., 1997; Dietz \& Rosa, 1994, 1997; Jorgenson \& Clark, 2010, 2013; Rosa, York, \& Dietz, 2004; York, 2007; York, Rosa, \& Dietz, 2003). However, the complex environmental effects of population growth, combined with other demographic factors, are less often documented. While population growth in poor nations, which tends to be higher than in rich nations, contributes to rising energy consumption and emissions, research in geography and sociology suggests that such growth threatens global climate stability less than wealthy nations' consumption practices do (Hubacek, Baiocchi, Feng, \& Patwardhan, 2017; Jorgenson \& Clark, 2013).

Beyond population size and growth, other demographic characteristics with important implications for emissions include age distribution, number of households, and average household size in a given population (Adua, York, \& Schuelke-Leech, 2016). Energy use and emissions tend to be higher when a larger share of the population is working aged (York, 2007). In developed countries, with larger aging populations, low fertility helps to suppress emissions, but the changing age structure only modestly limits emissions, at least in the short term (York, 2007). In some contexts, the number of households is a more important driver of environmental impacts than is the number of people (Liu, Daily, Ehrlich, \& Luck, 2003; York \& Rosa, 2012). Household size is declining in affluent nations, which leads to increases in energy consumption and carbon emissions (Weber \& Matthews, 2008). Average household size also has begun to decline in rapidly developing countries as well (Leichenko \& Solecki, 2005).

\section{4 | Land-use transformation}

Anthropologists, archeologists, geographers, and sociologists have demonstrated that land-use transformation is an underlying cause of anthropogenic climate change. Some evidence to support this conclusion is derived from the long, continuous record of human-induced changes. Land-use transformation results from contextual and proximate causes. Contextual causes include a range of international market and institutional arrangements. Proximate causes are human activities that more directly contribute to emissions.

Archeologists demonstrate that such alterations have a long time span, from the Holocene's beginning $(>10,000$ years ago) and extending through the era of widespread agriculture, especially since about 7,000 years ago (d'Alpoim Guedes, Crabtree, Bocinsky, \& Kohler, 2016; Erlandson \& Braje, 2013; Ruddiman, 2005; Ruddiman \& Ellis, 2009; Smith \& Zeder, 2013). Both land-use change and related biomass burning are important drivers of climate change in contemporary contexts; in particular, the agriculture, forestry, and other land-use sector contributes to about $25 \%$ of net anthropogenic emissions, mainly from deforestation, agricultural soil- and nutrient-management practices, and livestock (IPCC, 2014b).

Research in geography, anthropology, and sociology focuses on how interrelationships among national politics, international treaties, stratification, regions and scales combine to impact land use and land cover change at the district or municipal level (Smith et al., 2014). Proximate causes relate to a variety of household, community, and local infrastructural conditions (Rudel, 2005; Seto, Solecki, \& Griffith, 2016; Turner, Moss, \& Skole, 1993). Social scientists commonly study land transformation in rural domains, including the tropics, where they address the social and institutional processes of deforestation (Rudel, 2005). As important, their analyses of urban, suburban, and exurban land-use and land-cover change are critical for understanding urban residents' resource-consumption patterns and associated greenhouse gas emissions (Leichenko \& Solecki, 2005; Marcotullio et al., 2014; Romero-Lankao et al., 2014; Rudel, 2009). 
Landscape changes are also connected to large-scale capital investments, including hydroelectric dam construction, largescale irrigation, and wetland drainage that permanently change local ecosystems. For example, Brazil's history of highway and hydro-electric dam infrastructure development in the Amazon demonstrates how investments can lead to unanticipated and unsustainable population booms. These booms not only lead to challenges in human wellbeing through a lack of services, economic inequalities and loss of livelihood, but also related ecological challenges like deforestation, with attendant climate consequences (Fearnside, 1999; Moran, 2016; Richter et al., 2010; Walker, Moran, \& Anselin, 2000). National governments often play active roles in development that results in deforestation, while local growth coalitions press for road building and development, even when national governments pull back from deforestation-causing activities (Rudel, 2009).

\section{3 | MITIGATION AND ADAPTATION}

Human responses to the risks and impacts of climate change largely fit into two categories: mitigation and adaptation (IPCC, 2014a, 2014b, 2014c). "Mitigation" refers to a human intervention to reduce the sources or enhance the sinks of carbon and other GHG (IPCC, 2014b). "Adaptation" refers to adjustments in natural or human systems in response to actual or expected climatic stimuli or their effects; such adjustments moderate harm or exploit beneficial opportunities (IPCC, 2014a). Both mitigation and adaptation occur at various spatial and temporal scales, using approaches that apply technological, economic, institutional, regulatory, ecosystem-based, informational, and social factors (Carmin et al., 2015; Rosenzweig et al., 2018). In addition, mitigation and adaptation decisions are subject to path-dependency, meaning current options are often constrained by the outcomes of past decisions (Ehrhardt-Martinez, Rudel, Norgaard, \& Broadbent, 2015). While the drivers of increasing atmospheric concentrations of GHG are largely international and global, the effects of contemporary climate change are experienced locally (Miller Hesed \& Paolisso, 2015). This section discusses how approaches to mitigating and adapting to climate change are influenced by both long-term and near-term social processes as well as relationships between various actors.

\section{1 | Temporal contexts}

By looking at long-term changes from the past, archeology demonstrates that similar outcomes occurred in different areas that were affected by local climate change patterns (Redman, 1999). For example, the Long Term Vulnerability and Transformations Project based at Arizona State University, in collaboration with the North Atlantic Biocultural Organization, compares multiple societies' responses to sudden impacts of climate change in the thirteenth through fifteenth centuries CE. While the environment and societies were radically different, cases of successful adaptation had common underlying structural patterns. Although researchers have also identified painful transitions and full-scale societal collapse, common successful adaptations include balancing population size against available resources, having a diverse portfolio of food and other choices, social networks that reduce risk, storage systems, mobility and migration, equal access to resources, and reduction of barriers to resources (Nelson et al., 2016). Historically, resistance to adopting tools from other cultures and over-commitment to forms of fixed infrastructure, such as irrigation, have often led to adverse path dependency. Societal collapse is known to be associated with inflexible or out-of-phase management responses and the depletion of the social capital that legitimizes collective responses. Research by Chase and Scarborough (2014) suggests that collapse generally takes place well before total resource depletion and should therefore be understood as a management failure.

As it provides temporal context and shows longer term pathways, archeology also offers insights that can articulate with the shorter temporal scales that other social sciences usually consider. Historical ecological research, by combining archeology and history with other environmental social sciences and humanities, local and traditional knowledge, paleoecology, and the perspectives of modern resource managers, offers a broad framework for understanding deep time perspectives on human responses to and effects on climate change (Armstrong et al., 2017; Balée, 2006; Balée \& Erickson, 2006; Braje, 2015; Braje \& Rick, 2013; Burgi, 2011; Costanza et al., 2012; Egan \& Howell, 2001; Hicks et al., 2016; Jackson \& Hobbs, 2009; Meyer \& Crumley, 2011; Rick \& Lockwood, 2013).

The Resilience Alliance (2010) uses adaptive-management strategies that draw upon long-term perspectives developed through archeology. The Resilience Alliance and other interdisciplinary networks of scientists and practitioners work on not only improving response to sudden (often catastrophic) threshold crossing events but also identifying warning signals that such thresholds are being approached (i.e., forecasting tipping points, while there may still be time to mitigate and adapt). Threshold crossings are normally a complex mix of environmental and social factors, and developing a wider spectrum of such "red flag" variables can alert managers to oncoming transformations. For example, Streeter, Dugmore, Lawson, Erlendsson, and Edwards (2015) combine social and environmental variables and innovative use of volcanic tephra (ash) horizons in Iceland to mark human impacts on the Icelandic environment. 
One component affecting this is the problem of Shifting Baselines, in which successive generations of resource managers perceive their current conditions as a natural baseline without recognizing longer term trends and patterns of simplification and degradation (Olson, 2002). This problem is well-documented in fisheries and marine resource management (Campbell, Gray, Hazen, \& Shackeroff, 2009; Pauly, 1995), but extends across terrestrial situations as well. For example, Engelhard, Righton, and Pinnegar (2014) have noted in an analysis of 100 years of North Sea cod distribution that both climate change and fishing pressure impact fish distributions.

\section{2 | Governance}

In the area of governance and policy, the role and structure of international environmental agreements have been examined through multiple social science perspectives.

World Society Theory, a neo-institutional tradition within sociology, highlights the role of global institutional structures in influencing social change and environmental outcomes (Meyer, Boli, Thomas, \& Ramirez, 1997). World Society Theory argues that nation-states are socially constructed actors embedded in a transnational system of structures, agents, and norms that legitimate and encourage some actions and not others. A central actor within world society theory is the International Nongovernmental Organization (INGO). Environmental INGOs are theorized to both reflect and carry forth the content of world society to nation-states and subnational actors (Longhofer \& Schofer, 2010). Studies in this tradition have found that ties to the pro-environmental world society (a stronger presence of environmental INGOs) are associated with modest reductions in national-level carbon emissions (Givens, 2017; Hironaka, 2014; Schofer \& Hironaka, 2005; Shandra, London, Whooley, \& Williamson, 2004). Research in this tradition also indicates that the effect of economic growth on carbon emissions has moderately decreased in magnitude through time in nations that are most central in the global network of environmental INGOs (Longhofer \& Jorgenson, 2017). In other words, world society integration can help facilitate a decoupling between economic development and emissions.

Research in political sociology also shows the importance of governance structure. A recent study employs multilevel modeling techniques to analyze carbon emissions from fossil-fuel power plants in the 25 post-Soviet transition nations in Central and Eastern Europe and Eurasia (Jorgenson, Longhofer, Grant, Sie, \& Giedraitis, 2017). Various plant-level factors are associated with higher emissions, including coal as the primary fuel source, plant size and age, capacity utilization rate, and heat rate. Regarding governance, results indicate that plant-level emissions are lower, on average, in the transition nations that joined the European Union (EU), whose market reforms and environmental directives are quite relevant for emissions reductions. These negative associations between plant-level emissions and EU accession are larger for the post-Soviet nations that joined the EU earlier relative to those that joined more recently.

In the United States as well, environmental regulations can lead to reductions in carbon emissions from fossil-fuel burning power plants. Analyzing plant-level and state-level data with multilevel modeling techniques, sociologists Grant, Bergstrand, and Running (2014) assess state policy effects on individual power plants' emissions. Both direct strategies, such as emission caps and targets, and indirect strategies, such as public benefit funds, lower plants' emissions and thus can be viable building blocks in a federal climate regime. Other recent research, using longitudinal data from all 50 U.S. states, indicates that the effects of population and affluence on state-level carbon emissions are substantially moderated by congressional representatives' pro-environmental voting (Dietz, Frank, Whitley, Kelly, \& Kelly, 2015). Political-institutional factors, such studies show, can ameliorate the environmental effects of economic and demographic factors.

Other bodies of research in sociology and geography have pointed to subnational opportunities to fill what has been called a climate "policy void" in U.S. politics (Fisher, 2013; Jones, 1991; Krane, 2007; Rabe, 2007; Shwom, 2011). In some cases, this work encourages the multi-level governance of climate change, which crosses scales and frequently involves a broader range of policy actors in the decision-making process (Bulkeley, 2005; Galli \& Fisher, 2016). Research in this area also maps out how networks of policy elites are engaging in the climate debate (Fisher et al., 2018; Fisher, Leifeld, \& Iwaki, 2013; Fisher, Waggle, \& Leifeld, 2013). Similar claims are made in the social science literature on polycentric governance (Cole, 2015; Dorsch \& Flachsland, 2017; Gillard, Gouldson, Paavola, \& Van Alstine, 2017; Hsu, Weinfurter, \& Xu, 2017; Ostrom, 2014; Spreng, Sovacool, \& Spreng, 2016), with some focus on global climate politics since the Paris Agreement was signed in 2015 (Oberthür, 2016; Victor et al., 2017). Polycentricity refers to a form of governance with multiple centers of semiautonomous decision making. Scholars have argued that if decision-making centers take each other into account in competitive and cooperative relationships and have recourse to conflict resolution mechanisms, they may be regarded as a polycentric governance system (Carlisle \& Gruby, 2017).

Anthropologists have engaged political ecology theories to analyze the effectiveness of governance structures and approaches. Focusing on resource management and the commons, such research has assessed the role of the state and private property with respect to tragedies of the commons where individuals in a shared-resource context are posited to act for their 
own individual interests. This is common in smaller-scale societies, but also found in developed nations where local control is embedded in a national framework (McCay \& Acheson, 1987; Pinkerton, 2011).

Global mitigation policies, developed to reduce deforestation and increase carbon sequestration in the world's forests, include CDM (Clean Development Mechanism), REDD (Reducing Emissions from Deforestation in Developing Countries), and REDD+ (Reducing Emissions from Deforestation and Forest Degradation in Developing Countries). Globally, while REDD and REDD+ have enhanced stewardship and reduced land degradation, deforestation continues to increase in Indonesia, Malaysia, and parts of Africa and South America, and the discontinuities between top-down policies with activities occurring at the project or community level can be seen in the implementation of such programs. Concerns have arisen about equity and the policies' effectiveness (Harlan, Pellow, \& Roberts, 2015; Paladino \& Fiske, 2017; Parks \& Roberts, 2010). In an examination of 9 cases in Uganda, $\mathrm{Nel}(2015,2017)$ finds that benefits are asymmetrical, and local people are often affected by "expulsion and marginalization". However, research on the Khasi Hills Project in India indicates that community-based forest management has the potential to provide an effective strategy for mitigating powerful drivers of deforestation, and can be even more successful if supported through internationally recognized and certified carbon projects, including both REDD+ and Afforestation and Reforestation (Poffenberger, 2017). The concept of REDD+ is evolving and one of the more promising approaches is "Jurisdictional REDD," which spans different land-use types across landscapes and with multiple stakeholders in a subnational jurisdiction (Fishbein \& Lee, 2015). More broadly, this area of research indicates that global-scale initiatives need to connect more effectively to local environmental and social contexts (Angelsen \& Rudel, 2013; Fiske et al., 2014; Lansing, 2012; Leach \& Scoones, 2015; Paladino \& Fiske, 2017).

CDMs use carbon offsets to manage anthropogenic climate change, generally by harnessing technology or engineered solutions through large-scale energy generation plants or chemical manufacturing facilities that use technology to capture carbon. Social science critiques have identified limitations of CDM programs and policies. For instance, capital flows from offsetting in the compliance market mirror distributional inequities of direct foreign investment: sub-Saharan Africa attracts less than $2 \%$ of such investment, while China, Brazil, and India - the three largest recipients-together receive the bulk of the CDM investment (Bailey, Gouldson, \& Newell, 2012). In addition, there are numerous unrealized goals, including generating carbon-reducing activities and projects promoting cobenefits for more sustainable community-level development (Bailey et al., 2012). Among other areas of concern addressed in the social science literature on CDMs are institutional structures, including the use of markets, and unintended incentives and consequences (Boyd et al., 2009; Boyd, Boykoff, \& Newell, 2012; Boyd, Gutierrez, \& Chang, 2007; Brown \& Corbera, 2003; Finley-Brook, 2016).

\section{3 | Technology}

Energy use has evolved over millennia, and because its current concentration in fossil fuels is integral to economic growth, changing that concentration will likely be difficult within the structure of the contemporary world economy (Antonio \& Clark, 2015; Chase-Dunn, 1998; Clark \& York, 2005; Hornborg, 2013; Rosa et al., 2015; Smil, 2010; Strauss, Rupp, \& Love, 2013; Urry, 2016; White, 2016). Technological options often provide short-term fixes but often have long-term, unanticipated, impacts. For example, increasing energy efficiency through technological innovations is often assumed to be an effective strategy for reducing energy consumption and associated greenhouse gas emissions. Efficiency lowers the price of energy and related services, however, so it may increase demand for them and thereby cause total emissions to rise-a point that William Stanley Jevons first argued in the nineteenth century (York \& McGee, 2016), and similar to what is commonly referred to as "rebound effects."

Sociologists Grant, Jorgenson, and Longhofer (2016) analyze a dataset containing nearly every fossil fuel power plant in the world with multilevel modeling techniques to determine whether the impact of efficiency on emissions varies by plants' age, size, and location in global economic and normative systems. Their findings indicate that each of these factors has a significant interaction with efficiency and thus shapes environmentally destructive rebound effects. Related research finds that the dirtiest 5\% of fossil fuel power plants in nations throughout the world are disproportionately responsible for large shares of their sectors' total emissions. If these plants continued generating the same amount of electricity but met particular intensity targets through enhanced efficiencies or through other means, the world's total electricity-based carbon emissions could be reduced by as much as 40\% (Grant, Jorgenson, \& Longhofer, 2013; Jorgenson, Longhofer, \& Grant, 2016).

In an effort to effectively identify hyper-polluting plants throughout the world that are disproportionately responsible for the electricity generation sector's total emissions, Grant, Jorgenson, and Longhofer (2018) employ qualitative comparative analysis (QCA) techniques to analyze the conjoint effects of global, political, and organizational conditions on fossil-fueled plants' carbon emissions. QCA treats cases as combinations of attributes and uses Boolean algebra to derive expressions of combinations associated with an outcome. Such a technique is well suited to evaluate higher-order interactions and determine which of several possible combinations of factors are most relevant for an outcome. Their findings reveal that hyper-polluters' emission rates are a function of four distinct causal recipes, which they label coercive, quiescent, expropriative, and inertial 
configurations, and these same sets of conditions also increase plants' emission levels (Grant et al., 2018). Coercive and quiescent configurations enhance plants' ability to externalize their carbon emissions by neutralizing and manipulating potential sources of resistance, whereas expropriative and inertial configurations inhibit plants' ability to curb emissions by subjecting them to opportunistic behavior and forces of inertia.

An important example of the unanticipated consequences of technological change is the role of renewable energy: it is not necessarily the case that adding renewable energy sources without structural changes to the economy will reduce fossil fuel use. Sociological research by York (2012b) indicates that in nations around the world since 1960, growth in nonfossil fuel sources only minimally displaced fossil fuel use (controlling for economic growth, population growth, and other factors) - that is, nonfossil energy sources were largely added to, rather than in place of, fossil energy sources (see also Greiner, York, \& McGee, 2018; Thombs, 2018b). This finding, although superficially surprising, fits with a long tradition of research in technology studies which finds that technologies often have unanticipated consequences, due to interactions with social, economic, and political forces. Other sociological research suggests that interactions between the increasing use of renewable energy sources and economic growth may also lead to a tighter coupling of GDP to carbon emissions because renewables are more likely to be used to replace nuclear power than to replace fossil fuels, thus maintaining the dominance of fossil fuels as the base load electricity source (Thombs, 2017; York, 2016, 2017; York \& McGee, 2017).

However, it may be feasible to achieve near-term reductions in carbon emissions by the adoption and use of readily available technologies, according to a study of U.S. homes and nonbusiness travel (Dietz et al., 2009). Dietz and colleagues use data on the most-effective documented interventions to estimate the plasticity (which measures the ease and speed of change) of 17 household action types in behaviorally distinct categories. These interventions involved several policy tools and strong social marketing but not new regulatory measures. Within 10 years, they estimate, nationwide implementation could save 123 million metric tons of carbon with little or no reduction in household well-being (see also Shwom \& Lorenzen, 2012).

\section{4 | Decarbonization}

Research on decarbonization has focused on evaluating the feasibility, technology pathways, and costs of near-term and longterm mitigation scenarios. Many scenario studies of long-term climate stabilization use modeling frameworks with representation of the global energy economy (Fawcett et al., 2015; IPCC, 2007, 2014b; Riahi, Gruebler, \& Nakicenovic, 2007), while other scenario modeling research focuses more narrowly, on such cases as the U.S. economy (Paltsev, Reilly, Jacoby, \& Morris, 2009; Risky Business Project, 2016) and energy sectors (McCollum \& Yang, 2009). Some research in geography and related fields separates sector, region, city, and time periods to address infrastructure changes, technology deployment, sectoral investment, and associated behavioral patterns of low-carbon transitions (Bataille, Waisman, Colombier, Segafredo, \& Williams, 2016; C40 and Arup, 2016; Mileva, Johnston, Nelson, \& Kammen, 2016; Solecki et al., 2018). Scenario-based projections suggest potential opportunities for decoupling economic growth from global- and local-scale carbon emissions (Loo \& Banister, 2016; Shen \& Sun, 2016), while research at municipal and neighborhood levels defines differential emissions rates under different socioeconomic conditions and ecosystem regimes (Hardiman et al., 2017; Liu, Ma, \& Chai, 2017).

However, current knowledge about transitions to a low-carbon economy and deep decarbonization is limited by a lack of empirical evidence: there are no known cases in which societies or nations have deliberately and systematically deeply decarbonized. Nonetheless, the conditions and prospects of a socially feasible decarbonization transition are increasingly addressed in social science literature. The issues considered include governance capacity; social, political and institutional adjustments across different scales; dimensions of well-being; attitudes and behavior; benefits; innovation diffusion; equity and justice; conditions of data; information limitations and uncertainty (Betsill \& Bulkeley, 2006; Busby \& Shidore, 2017; Byravan et al., 2017; Geels, Sovacool, Schwanen, \& Sorrell, 2017). Cobenefits of climate change mitigation are also examined (Ibrahim, 2017), and a growing literature considers such applications in cities and urban contexts (Bulkeley, Edwards, \& Fuller, 2014; Hodson, Geels, \& Mcmeekin, 2017; Hughes, 2017; Luque, Edwards, \& Lalande, 2013; McGuirk, Bulkeley, \& Dowling, 2016).

\section{I CONCLUSION}

This article has summarized bodies of recent research in anthropology, archeology, geography, and sociology on the drivers of climate change, with a focus on the anthropogenic drivers of carbon emissions and factors that influence the effectiveness of mitigation and adaptation strategies. As a whole, the research reviewed from these social science disciplines highlights that among the key human factors contributing to climate change are the roles of and connections among economic conditions and development; demographic growth and changes; power, social stratification and inequality; technology; infrastructure; and 
land-use change. These factors' near- and long-term dynamic interactions across spatial scales and institutional contexts shape the pathways and options for mitigation and adaptation.

Economic activities, and associated growth in income and consumption are major drivers of carbon emissions. Power, social stratification and forms of inequality are often key factors that shape outcomes, including carbon emissions at national and subnational levels. Analyses at the micro-level, such as the household, and in particular spaces, such as urban areas, emphasize that sociocultural contexts are important for understanding consumption as a driver. Population growth is a major driver of climate change, but not all humans contribute equally to carbon emissions.

Land use and land transformation are important drivers of climate change because they result from complex interactions on multiple levels. Significant aspects include global treaties, global and local economic forces, national policies and politics, urban-rural relationships, household behaviors, and local infrastructure. Along with exploring this complexity, the social sciences offer alternative adaptation and mitigation strategies that take into account historical ecology and different temporalscale relationships between the natural world and the social world.

Long-term perspectives on drivers of climate change and human pathways help in comprehending thresholds and tippingpoints and in building planning scenarios. Understanding the current impact of past human activities and the long-term evolutionary processes that drive human behaviors are critical not only for understanding the drivers of climate change but also for creating mitigation and adaptation efforts. Effective global-scale policies and initiatives must connect to regional and local conditions and social contexts.

Decarbonization requires dramatic changes in energy systems and policies. Consideration of how policies influence not only the availability of low- and noncarbon energy technologies but also total energy production and consumption can lead to more sustainable outcomes. Technologies have unintended and unanticipated consequences due to interactions with social, economic, and political forces. In order to effectively reduce carbon emissions, structural changes, such as reducing income inequality, increasing sustainable consumption, and implementing effective regulatory mechanisms, are all necessary.

The areas of social science literature reviewed in this article point to multiple avenues for future data collection and research. First, there is a significant need to fill data gaps at household, community, and other local levels on drivers as well as mitigation- and adaptation-related issues. Second, we need to increase our understanding of consumer demands, choices, and commodity use, all of which will help target areas in which to reduce emissions. Third, there remains a need to integrate more fully knowledge of physical and social systems, both for understanding driver-related pathways and for creating successful adaptation and mitigation opportunities.

A fourth important area to address is developing clearer pathways on all levels for moving historical data and knowledge into praxis. Important considerations are renewable energy and jobs production, household and industry subsidies for renewable energy adoption, alternative models for economic growth, and how to decarbonize while ensuring ecologically sustainable and socially equitable development. Fifth, there is a need for much more systematic cross-regional comparisons of cases involving long-term human environmental dynamics, which could aid in generalizing about long-term lessons.

Sixth, there is a need for improvements in forecasting thresholds and tipping points of both social and natural systems. These improved predictions are needed for societal responses to sudden, often catastrophic threshold-crossing events and warnings of their approach while there is still time to mitigate and plan for adaptation. A seventh area for future attention is correcting assumptions about shifting baselines. Problems arise when successive generations of resource managers and researchers perceive current conditions as a natural baseline against which to evaluate future events, rather than recognize long-term trends and patterns of simplification and degradation that may have occurred in prior decades, centuries, or millennia.

Eighth, traditional carbon emissions accounting (e.g., territorial or production-based), does not measure the extent to which environmentally harmful production is outsourced abroad. Consumption-based accounting, by shifting system boundaries, facilitates tracking carbon emissions along regional and global supply chains, and reallocates those emissions to the final consumer. Thus, research that focuses on international inequality perspectives, such as ecologically unequal exchange, would do well to analyze both consumption-based and production-based measures of emissions.

Finally, research questions must focus more directly on the relationship between decarbonization and economic growth. With this, studies are needed of the social-structural, institutional, technological, and behavioral conditions that would ensure socially feasible decarbonization transitions, especially given the scale of carbon sequestration required and the associated impacts on land use and food prices, and the ways in which a low-carbon economy would affect individual well-being and social equity.

\section{ACKNOWLEDGMENTS}

This article was developed from a workshop "Social Science Perspectives on Climate Change" held in Washington, DC in March 2017. Funding for the workshop and manuscript development was provided by the National Aeronautics and Space 
Administration (grant NNX17AG17G), the U.S. Bureau of Land Management, the American Anthropological Association, the American Association of Geographers, the American Sociological Association, and the Society for American Archaeology. We also wish to acknowledge support provided by Skye Sieber, Katie Reeves and Blenda Femenias and helpful comments provided by Chelsey Armstrong, Nancy Cavallaro, Lesley Jantarasami, James McFarland, Andy Miller, Jennifer Saleem-Arrigo, Gyami Shrestha, and Paul Stern, as well as from the anonymous reviewers. Disclaimer: The views expressed in this article are the authors' and do not represent the policies of any U.S. government agency. [Correction added on 20 September 2018, after first online publication: Funding information, Acknowledgments section, and Disclaimer have been inserted.]

\section{CONFLICT OF INTEREST}

The authors have declared no conflicts of interest for this article.

\section{RELATED WIRES ARTICLES}

$\underline{\text { Human well-being and climate change mitigation }}$

\section{FURTHER READING}

Jorgenson, A., \& Clark, B. (2016). The temporal stability and developmental differences in the environmental impacts of militarism: The treadmill of destruction and consumption-based carbon emissions. Sustainability Science, 11, 505-514.

World Bank. (2017). World development indicators. Retrieved from http://data.worldbank.org/data-catalog/world-development-indicators

\section{REFERENCES}

Adua, L., York, R., \& Schuelke-Leech, B. (2016). The human dimensions of climate change: A micro-level assessment of views from the ecological modernization, political economy and human ecology perspectives. Social Science Research, 56, 26-43.

Angelsen, A., \& Rudel, T. (2013). Designing and implementing effective REDD+ policies: A forest transition approach. Review of Environmental Economics and Policy, 7, 91-113.

Antonio, R., \& Clark, B. (2015). The climate change divide in social theory. In R. Dunlap \& R. Brulle (Eds.), Climate change and society: Sociological perspectives. Oxford, England: Oxford University Press.

Armstrong, C. G., Shoemaker, A. C., McKechnie, I., Ekblom, A., Szabó, P., Lane, P. J., ... Crumley, C. L. (2017). Anthropological contributions to historical ecology: 50 questions, infinite prospects. PLoS ONE, 12(2), e0171883. https://doi.org/10.1371/journal.pone.0171883

Bailey, I., Gouldson, A., \& Newell, P. (2012). Ecological modernisation and the governance of carbon. In P. Newell, M. Boykoff, \& E. Boyd (Eds.), The new carbon economy: Constitution, governance and contestation (pp. 85-106). West Sussex, England: Wiley-Blackwell.

Baiocchi, G., Minx, J., \& Hubacek, K. (2010). The impact of social factors and consumer behavior on CO2 emissions in the UK: A panel regression based on input-output and geo-demographic consumer segmentation data. Industrial Ecology, 14(1), 50-72.

Balée, W. (2006). The research program of historical ecology. Annual Review of Anthropology, 35(5), 15-24.

Balée, W., \& Erickson, C. (Eds.). (2006). Time and complexity in historical ecology: Studies in the neotropical lowlands. New York, NY: Columbia University Press.

Bataille, C., Waisman, H., Colombier, M., Segafredo, L., \& Williams, J. (2016). The Deep Decarbonization Pathways Project (DDPP): Insights and emerging issues. Climate Policy, 16(sup1), S1-S6. https://doi.org/10.1080/14693062.2016.1179620

Baudrillard, J. (2017). The consumer society: Myths and structures. Los Angeles, CA: Sage.

Betsill, M. M., \& Bulkeley, H. (2006). Cities and the multilevel governance of global climate change. Global Governance, 12(2), 141-159.

Bowles, S., \& Park, Y. (2005). Emulation, inequality, and work hours: Was Thorsten Veblen right? Economic Journal, 115(507), F397-F412.

Boyd, E., Boykoff, M., \& Newell, P. (2012). The "new" carbon economy: What's new? In P. Newell, M. Boykoff, \& E. Boyd (Eds.), The new carbon economy: Constitution, governance and contestation (pp. 1-11). West Sussex, England: Wiley-Blackwell.

Boyd, E., Gutierrez, M., \& Chang, M. (2007). Small-scale forest carbon projects: Adapting CDM to low-income communities. Global Environmental Change, 17(2), 250-259.

Boyd, E., Hultman, N., Roberts, J. T., Corbera, E., Cole, J., Bozmoski, A., ... Tippman, R. (2009). Reforming the CDM for sustainable development: Lessons learned and policy futures. Environmental Science \& Policy, 12(7), 820-831.

Bradford, J., \& Stoner, A. (2017). The treadmill of destruction in comparative perspective: A panel study of military spending and carbon emissions, 1960-2014. Journal of World-Systems Research, 23(2), 298-325.

Braje, T. J. (2015). Earth systems, human agency, and the Anthropocene: Planet Earth in the human age. Journal of Archaeological Research, $23,369-396$.

Braje, T. J., \& Rick, T. C. (2013). From forest fires to fisheries management: Anthropology, conservation, and historical ecology. Evolutionary Anthropology, 22, 303-311.

Brown, K., \& Corbera, E. (2003). Exploring equity and sustainable development in the new carbon economy. Climate Policy, 3(Supplement 1), S41-S56.

Bulkeley, H. (2005). Reconfiguring environmental governance: Towards a politics of scales and networks. Political Geography, $24,875-902$.

Bulkeley, H., Edwards, G. A. S., \& Fuller, S. (2014). Contesting climate justice in the city: Examining politics and practice in urban climate change experiments. Global Environmental Change, 25, 31-40.

Bunker, S. (1984). Modes of extraction, unequal exchange, and the progressive underdevelopment of an extreme periphery: The Brazilian Amazon, 1600-1980. American Journal of Sociology, 89, 1017-1064.

Burgi, M. (2011). Frontiers in historical ecology. IUFRO News, 40, 3.

Burns, T., Davis, B., \& Kick, E. (1997). Position in the world-system and national emissions of greenhouse gases. Journal of World-Systems Research, 3, $436-466$.

Busby, J. W., \& Shidore, S. (2017). When decarbonization meets development: The sectoral feasibility of greenhouse gas mitigation in India. Energy Research \& Social Science, 23, 60-73. 
Byravan, S., Ali, M. S., Ananthakumar, M. R., Goyal, N., Kanudia, A., Ramamurthi, P. V., .. Paladugula, A. L. (2017). Quality of life for all: A sustainable development framework for India's climate policy reduces greenhouse gas emissions. Energy for Sustainable Development, 39, 48-58.

C40 and Arup. (2016). Deadline 2020: How U.S. cities will get the job done. Retrieved from http://publications.arup.com/publications/d/deadline_2020

Campbell, L. M., Gray, N. J., Hazen, E. L., \& Shackeroff, J. M. (2009). Beyond baselines: Rethinking priorities for ocean conservation. Ecology and Society, 14(1), Art-14.

Carlisle, K., \& Gruby, R. (2017). Polycentric systems of governance: A theoretical model for the commons. Policy Studies Journal. https://doi.org/10.1111/psj.12212

Carmin, J., Tierney, K., Chu, E., Hunter, L., Roberts, T., \& Shi, L. (2015). Adaptation to climate change. In R. Dunlap \& R. Brulle (Eds.), Climate change and society: Sociological perspectives. Oxford, England: Oxford University Press.

Chase, A. F., \& Scarborough, V. (2014). Diversity, resiliency, and IHOPE Maya: Using the past to inform the present. Archaeological Papers of the American Anthropological Association, 24(1), 1-10. https://doi.org/10.1111/apaa.12025

Chase-Dunn, C. (1998). Global formation: Structures of the world economy. Lanham, MD: Rowman \& Littlefield.

Chase-Dunn, C., \& Grimes, P. (1995). World-systems analysis. Annual Review of Sociology, 31, 387-417.

Clark, B., \& Jorgenson, A. (2012). The treadmill of destruction and the environmental impacts of militaries. Sociology Compass, 6(7), 557-569.

Clark, B., Jorgenson, A., \& Kentor, J. (2010). Militarization and energy consumption: A test of treadmill of destruction theory in comparative perspective. International Journal of Sociology, 40, 23-43.

Clark, B., \& York, R. (2005). Carbon metabolism: Global capitalism, climate change, and the biospheric rift. Theory and Society, 34, 391-428.

Cole, D. (2015). Advantages of a polycentric approach to climate change policy. Nature Climate Change, 5(2), 114-118.

Collins, M. B., Munoz, I. A., \& JaJa, J. (2016). Linking "toxic outliers" to environmental justice communities across the United States. Environmental Research Letters, $11,1-9$.

Costanza, R., van der Leeuw, S., Hibbard, K., Aulenbach, S., Brewer, S., Burek, M., ... Steffen, W. (2012). Developing an integrated history and future of people on earth (IHOPE). Current Opinion in Environmental Sustainability, 4(1), 106-114.

d'Alpoim Guedes, J., Crabtree, S. A., Bocinsky, R. K., \& Kohler, T. A. (2016). Twenty-first century approaches to ancient problems: Climate and society. Proceedings of the National Academy of Sciences, 113, 14483-14491.

Dietz, T. (2015). Prolegomenon to a structural human ecology of human well-being. Sociology of Development, 1(1), 123-148.

Dietz, T. (2017). Human drivers of environmental change. Annual Review of Environment and Resources, 42, 189-213.

Dietz, T., Frank, K., Whitley, C., Kelly, J., \& Kelly, R. (2015). Political influences on greenhouse gas emissions from US states. Proceedings of the National Academy of Sciences, 112, 8254-8259.

Dietz, T., Gardner, G., Gilligan, J., Stern, P., \& Vandenbergh, M. (2009). Household actions can provide a behavioral wedge to rapidly reduce US carbon emissions. Proceedings of the National Academy of Sciences, 106, 18452-18456.

Dietz, T., \& Rosa, E. (1994). Rethinking the environmental impacts of population, affluence and technology. Human Ecology Review, 1(2), 277-300.

Dietz, T., \& Rosa, E. (1997). Effects of population and affluence on $\mathrm{CO}_{2}$ emissions. Proceedings of the National Academy of Sciences, 94, 175-179.

Dietz, T., Rosa, E., \& York, R. (2009). Efficient well-being: Rethinking sustainability as the relationship between human well-being and environmental impacts. Human Ecology Review, 16, 114-123.

Dietz, T., Rosa, E., \& York, R. (2010). Human driving forces of global change: Dominant perspectives. In E. Rosa, A. Diekmann, T. Dietz, \& C. Jaeger (Eds.), Human footprints on the global environment: Threats to sustainability (pp. 83-134). Cambridge: MIT Press.

Dietz, T., Rosa, E., \& York, R. (2012). Environmentally efficient well-being: Is there a Kuznets curve? Applied Geography, 32, 21-28.

Dietz, T., Sovacool, B., \& Stern, P. (2016). Reply to 'broaden research on the human dimensions of climate change'. Nature Climate Change, 6, 1051.

Dietz, T., Stern, P., \& Weber, E. (2013). Reducing carbon-based energy consumption through changes in household behavior. Daedalus, 142(1), 78-89.

Dorsch, M., \& Flachsland, C. (2017). A polycentric approach to global climate governance. Global Environmental Politics, 17, 45-64.

Downey, L. (2015). Inequality, democracy, and the environment. New York, NY: NYU Press.

Egan, D., \& Howell, E. (Eds.). (2001). The historical ecology handbook: A restorationist's guide to reference ecosystems. Washington, DC: Island Press.

Ehrhardt-Martinez, K., Rudel, T., Norgaard, K., \& Broadbent, J. (2015). Mitigating climate change. In R. Dunlap \& R. Brulle (Eds.), Climate change and society: Sociological perspectives. Oxford, England: Oxford University Press.

Ehrhardt-Martinez, K., \& Schor, J. B. (2015). Consumption and climate change. In R. Dunlap \& R. Brulle (Eds.), Climate change and society: Sociological perspectives. Oxford, England: Oxford University Press.

Elliott, J., \& Clement, M. (2014). Urbanization and carbon emissions: A nationwide study of local countervailing effects in the United States. Social Science Quarterly, 95(3), 795-816.

Engelhard, G. H., Righton, D. A., \& Pinnegar, J. K. (2014). Climate change and fishing: A century of shifting distribution in North Sea cod. Global Change Biology, 20(8), 2473-2483. https://doi.org/10.1111/gcb.12513

Erlandson, J., \& Braje, T. (2013). Archaeology and the Anthropocene. Anthropocene, 4, 1-7.

Fawcett, A. A., Iyer, G. C., Clarke, L. E., Edmonds, J. A., Hultman, N. E., Haewon, ... Shi, W. (2015). Can Paris pledges avert severe climate change? Science, $350(6265), 1168-1169$.

Fearnside, P. (1999). Social impacts of Brazil's Tucuruí dam. Environmental Management, 24(4), 483-495.

Feng, K., Davis, S., Li, X., Guan, D., Sun, L., Liu, W., ... Hubacek, K. (2013). Outsourcing $\mathrm{CO}_{2}$ within China. Proceedings of the National Academy of Sciences, 110(28), 11654-11659.

Feng, K., Davis, S., Sun, L., \& Hubacek, K. (2015). Drivers of U.S. $\mathrm{CO}_{2}$ emissions 1997-2013. Nature Communications, 6, 8714.

Feng, K., Davis, S., Sun, L., \& Hubacek, K. (2016). Reply to contribution of natural gas to U.S. $\mathrm{CO}_{2}$ emission reductions since 2007 greater than proposed. Nature Communications, 7, 10693.

Feng, K., Hubacek, K., \& Yu, Y. (2014). China's unequal environmental exchange. Ecological Indicators, 47, 156-163.

Finley-Brook, M. (2016). Justice and equity in carbon offset governance: Debates and dilemmas. In S. Paladino \& S. Fiske (Eds.), The carbon fix: Forest carbon, social justice, and environmental governance (pp. 74-88). New York, NY: Routledge.

Fishbein, G., \& Lee, D. (2015). Early lessons from jurisdictional REDD+ and low emissions development programs. Arington, VA: The Nature Conservancy, World Bank, \& Forest Carbon Partnership Facility.

Fisher, D. (2013). Understanding the relationship between subnational and national climate change politics in the United States: Toward a theory of boomerang federalism. Environment and Planning. C, Government \& Policy, 31, 769-784.

Fisher, D., Galli Robertson, A., Waggle, J., Dewey, A., Dubin, A., \& Yagatich, W. (2018). Polarizing climate politics in America. Journal of Research in Political Sociology, 25, 1-23.

Fisher, D., Leifeld, P., \& Iwaki, Y. (2013). Mapping the ideological networks of American climate politics. Climatic Change, 116, 523-545.

Fisher, D., Waggle, J., \& Leifeld, P. (2013). Where does political polarization come from? Locating polarization within the US climate change debate. American Behavioral Scientist, 57, 70-92. 
Fiske, S. J., Crate, S. A., Crumley, C. L., Galvin, K., Lazrus, H., Lucero, ... Wilk, R. (2014). Changing the atmosphere. Anthropology and climate change. Final report of the AAA global climate change task force (p. 137). Arlington, VA: American Anthropological Association.

Fitzgerald, J., Jorgenson, A., \& Clark, B. (2015). Energy consumption and working hours: A longitudinal study of developed and developing nations, 1990-2008. Environmental Sociology, 1(3), 213-223.

Fitzgerald, J., Schor, J., \& Jorgenson, A. (2018). Working hours and carbon dioxide emissions in the United States, 2007-2013. Social Forces, 96(1), 1851-1874.

Galli, A., \& Fisher, D. (2016). Hybrid arrangements as a form of ecological modernization: The case of the US energy efficiency conservation block grants. Sustainability, $8(88), 1-19$.

Geels, F., Sovacool, B., Schwanen, T., \& Sorrell, S. (2017). Sociotechnical transitions for deep decarbonization. Science, 357(6357), $1242-1244$.

Gillard, R., Gouldson, A., Paavola, J., \& Van Alstine, J. (2017). Can national policy blockages accelerate the development of polycentric governance? Evidence from climate change policy in the United Kingdom. Global Environmental Change, 45, 174-182.

Givens, J. (2015). Urbanization, slums, and the carbon intensity of wellbeing: Implications for sustainable development. Human Ecology Review, 22, 107-128.

Givens, J. (2017). World society, world polity, and the carbon intensity of well-being, 1990-2011. Sociology of Development, 4, 403-435.

Givens, J. (2018). Ecologically unequal exchange and the carbon intensity of well-being, 1990-2011. Environmental Sociology, 4, 311-324. https://doi.org/10.1080/ 23251042.2018.1436878

Gould, K. (2007). The ecological costs of militarization. Peace Review: A Journal of Social Justice, 19(4), 331-334.

Gould, K., Pellow, D., \& Schnaiberg, A. (2008). The treadmill of production: Injustice and unsustainability in the global economy. Boulder, CO: Paradigm.

Grant, D., Bergstrand, K., \& Running, K. (2014). Effectiveness of US state policies in reducing $\mathrm{CO}_{2}$ emissions from power plants. Nature Climate Change, 4, $977-982$.

Grant, D., Jorgenson, A., \& Longhofer, W. (2013). Targeting electricity's extreme polluters to reduce energy-related CO2 emissions. Journal of Environmental Studies and Sciences, 3, 376-380.

Grant, D., Jorgenson, A., \& Longhofer, W. (2016). How organizational and global factors condition the effects of energy efficiency on $\mathrm{CO}_{2}$ emission rebounds among the world's power plants. Energy Policy, 94, 89-93.

Grant, D., Jorgenson, A., \& Longhofer, W. (2018). Pathways to carbon pollution: The interactive effects of global, political, and organizational factors on power plants' $\mathrm{CO}_{2}$ emissions. Sociological Science, 5, 58-92.

Graziano, M., \& Gillingham, K. (2015). Spatial patterns of solar photovoltaic system adoption: The influence of neighbors and the built environment. Journal of Economic Geography, 15(4), 815-839.

Greiner, P., \& McGee, J. (2018). Divergent pathways on the road to sustainability: A multilevel model of the effects of geopolitical power on the relationship between economic growth and environmental quality. Socius: Sociological Research for a Dynamic World, 4. https://doi.org/10.1177/2378023117749381

Greiner, P., York, R., \& McGee, J. (2018). Snakes in the greenhouse: Does increased natural gas use reduce carbon dioxide emissions from coal consumption? Energy Research and Social Science, 38, 53-57.

Grimes, P., \& Kentor, J. (2003). Exporting the greenhouse: Foreign capital penetration and CO2 emissions 1980-1996. Journal of World-Systems Research, 9(2), $261-275$.

Griskevicus, V., Tybur, J. M., \& Van Den Bergh, B. (2010). Going green to be seen: Status, reputation and conspicuous conservation. Journal of Personality and Social Psychology, 98(3), 392-404.

Hardiman, B. S., Wang, J. A., Hutyra, L. R., Gately, C. K., Getson, J. M., \& Friedl, M. A. (2017). Accounting for urban biogenic fluxes in regional carbon budgets. Science of the Total Environment, 592, 366-372.

Harlan, S. L., Pellow, D. N., \& Roberts, J. T. (2015). Climate justice and inequality. In R. E. Dunlap \& R. J. Brulle (Eds.), Climate change and society: A sociological perspectives (pp. 127-163). Oxford, England: Oxford University Press.

Hicks, M., Einarsson, Á., Anamthawat-Jónsson, K., Edwald, Á., Friðriksson, A., Pórsson, Æ. P., \& McGovern, T. H. (2016). Community and conservation: Documenting millennial scale sustainable resource use at Lake Mývatn Iceland. In C. Isendahl \& D. Stump (Eds.), The Oxford handbook of historical ecology and applied archaeology. Oxford, England: Oxford University Press.

Hironaka, A. (2014). Greening the globe: World society and environmental change. Cambridge, England: Cambridge University Press.

Hodson, M., Geels, F., \& Mcmeekin, A. (2017). Reconfiguring urban sustainability transitions, analysing multiplicity. Sustainability, 9, 299.

Hooks, G., \& Smith, C. (2004). The treadmill of destruction: National sacrifice areas and native Americans. American Sociological Review, 69(4), 558-575.

Hooks, G., \& Smith, C. (2005). Treadmills of production and destruction: Threats to the environment posed by militarism. Organization \& Environment, $18(1), 19-37$.

Hooks, G., \& Smith, C. (2012). The treadmill of destruction goes global: Anticipating the environmental impact of militarism in the 21 st century. In K. Gouliamos \& C. Kassimeris (Eds.), The marketing of war in the age of neo-militarism (pp. 60-83). London, England: Routledge.

Hornborg, A. (2013). Theorizing energy and culture. In Cultures of energy. Power, practices, technologies (pp. 41-59). Walnut Creek, CA: Left Coast Press.

Hornborg, A., \& Martinez-Alier, J. (2016). Ecologically unequal exchange and ecological debt. Journal of Political Ecology, 23, 328-333.

Hsu, A., Weinfurter, A., \& Xu, K. (2017). Aligning subnational climate actions for the new post-Paris climate regime. Climatic Change, 142, 419-432.

Huang, X. (2018). Ecologically unequal exchange, recessions, and climate change: A longitudinal study. Social Science Research, 73, 1-12.

Hubacek, K., Baiocchi, G., Feng, K., Muñoz Castillo, R., Prell, C., Sun, L, ... Xue, J. (2016). Carbon implications of consumption choices. Invited keynote lecture presented at the 24th international input-output conference, Seoul, Korea.

Hubacek, K., Baiocchi, G., Feng, K., Munoz Castillo, R., Sun, L., \& Xue, J. (2017a). Global carbon inequality. Energy, Ecology and Environment, 2(6), 361-369. https://doi.org/10.1007/s40974-017-0072-9

Hubacek, K., Baiocchi, G., Feng, K., Munoz Castillo, R., Sun, L., \& Xue, J. (2017b). Global income inequality and carbon footprints: Can we have the cake and eat it too? In Ó. Dejuán \& M. Á. Cadarso (Eds.), Environmental and economic impacts of decarbonization. Input-output studies on the consequences of the 2015 Paris agreements. Abington, England: Routledge.

Hubacek, K., Baiocchi, G., Feng, K., \& Patwardhan, A. (2017). Poverty eradication in a carbon constrained world. Nature Communications, 8, 912.

Huddart Kennedy, E., Krahn, H., \& Krogman, N. (2014). Egregious emitters: Disproportionality in household carbon footprints. Environment and Behavior, 46(5), 535-555.

Hughes, S. (2017). The politics of urban climate change policy: Toward a research agenda. Urban Affairs Review, 53(2), 362-380.

Ibrahim, N. (2017). Mitigation: Decarbonization unique to cities. Nature Climate Change, 7(10), 690.

IPCC. (2007). Climate change 2007: Synthesis report. In Core Writing Team, R. K. Pachauri, \& A. Reisinger (Eds.), Contribution of working groups I, II and III to the fourth assessment report of the Intergovernmental Panel on Climate Change. Geneva, Switzerland: Intergovernmental Panel on Climate Change.

IPCC. (2014a). Climate change 2014: Synthesis report. In Core Writing Team, R. K. Pachauri, \& L. A. Meyer (Eds.), Contribution of working groups I, II and III to the fifth assessment report of the Intergovernmental Panel on Climate Change. Geneva, Switzerland: Intergovernmental Panel on Climate Change.

IPCC. (2014b). Climate change 2014: Mitigation of climate change. In O. Edenhofer, R. Pichs-Madruga, Y. Sokona, E. Farahani, S. Kadner, K. Seyboth, \& J. C. Minx (Eds.), Contribution of working group III to the fifth assessment report of the Intergovernmental Panel on Climate Change. Cambridge, England: Cambridge University Press. 
IPCC. (2014c). Summary for policymakers. In O. Edenhofer, R. Pichs-Madruga, Y. Sokona, E. Farahani, S. Kadner, K. Seyboth, A. Adler, I. Baum, S. Brunner, P. Eickemeier, B. Kriemann, J. Savolainen, S. Schlömer, C. von Stechow, T. Zwickel, \& J. C. Minx (Eds.), Climate change 2014: Mitigation of climate change. Contribution of working group III to the fifth assessment report of the Intergovernmental Panel on Climate Change. Cambridge, England: Cambridge University Press.

Jackson, R. B., Canadell, J. G., Le Quéré, C., Andrew, R. M., Korsbakken, J. I., Peters, G. P., \& Nakicenovic, N. (2016). Reaching peak emissions. Nature Climate Change, 6, 7-10.

Jackson, S. T., \& Hobbs, R. (2009). Ecological restoration in the light of ecological history. Science, 325, 567-569.

Jones, B. (1991). State responses to global climate change. Policy Studies Journal, 19, 73-82.

Jorgenson, A. (2006). Unequal ecological exchange and environmental degradation: A theoretical proposition and cross-national study of deforestation, 1990-2000. Rural Sociology, 71, 685-712.

Jorgenson, A. (2007). Does foreign investment harm the air we breath and the water we drink? A cross-national study of carbon dioxide emissions and organic water pollution in less-developed countries, 1975-2000. Organization \& Environment, 20, 137-156.

Jorgenson, A. (2012). The sociology of ecologically unequal exchange and carbon dioxide emissions, 1960-2005. Social Science Research, 41, $242-252$.

Jorgenson, A. (2014). Economic development and the carbon intensity of human well-being. Nature Climate Change, 4, 186-189.

Jorgenson, A., Auerbach, D., \& Clark, B. (2014). The (de-) carbonization of urbanization, 1960-2010. Climatic Change, 127, 561-575.

Jorgenson, A., \& Clark, B. (2010). Assessing the temporal stability of the population/environment relationship: A cross-national panel study of carbon dioxide emissions, 1960-2005. Population and Environment, 32, 27-41.

Jorgenson, A., \& Clark, B. (2012). Are the economy and the environment decoupling? A comparative international study, 1960-2005. American Journal of Sociology, $118,1-44$.

Jorgenson, A., \& Clark, B. (2013). The relationship between national-level carbon dioxide emissions and population size: An assessment of regional and temporal variation, 1960-2005. PLoS ONE, 8(2), e57107.

Jorgenson, A., Clark, B., \& Kentor, J. (2010). Militarization and the environment: A panel study of carbon dioxide emissions and the ecological footprints of nations, 1970-2000. Global Environmental Politics, 10, 7-29.

Jorgenson, A., Dick, C., \& Mahutga, M. (2007). Foreign investment and the environment: An ecostructural approach. Social Problems, 54, 371-394.

Jorgenson, A., Longhofer, W., \& Grant, D. (2016). Disproportionality in power plants' carbon emissions: A cross-national study. Scientific Reports, 6, 28661.

Jorgenson, A., Longhofer, W., Grant, D., Sie, A., \& Giedraitis, V. (2017). The effects of political and economic integration on power plants' carbon emissions in the post-soviet transition nations. Environmental Research Letters, 12, 044009.

Jorgenson, A., Rice, J., \& Clark, B. (2010). Cities, slums, and energy consumption in less-developed countries, 1990-2005. Organization \& Environment, $23,189-204$.

Jorgenson, A., Schor, J., \& Huang, X. (2017). Income inequality and carbon emissions in the United States: A state-level analysis, 1997-2012. Ecological Economics, $134,40-48$.

Jorgenson, A., Schor, J., Knight, K., \& Huang, X. (2016). Domestic inequality and carbon emissions in comparative perspective. Sociological Forum, 31 , 770-786.

Kentor, J. (2000). Capital and coercion: The economic and military processes that have shaped the world economy 1800-1990. New York, NY: Garland.

Knight, K., Rosa, E., \& Schor, J. (2013). Could working less reduce pressures on the environment?: A cross-national panel analysis of OECD countries, 1970-2007. Global Environmental Change, 23, 691-700.

Knight, K., \& Schor, J. (2014). Economic growth and climate change: A cross-national analysis of territorial and consumption-based carbon emissions in high-income countries. Sustainability, 6(6), 3722-3731.

Knight, K., Schor, J., \& Jorgenson, A. (2017). Wealth inequality and carbon emissions in high-income countries. Social Currents, 4, 403-412.

Krane, D. (2007). The middle tier in American federalism: State government policy activism during the bush presidency. Publius: The Journal of Federalism, 37, 453-477.

Lansing, D. M. (2012). Realizing carbon's value: Discourse and calculation in the production of carbon forestry offsets in Costa Rica. In P. Newell, M. Boykoff, \& E. Boyd (Eds.), The new carbon economy: Constitution, governance and contestation (pp. 135-157). West Sussex, England: Wiley-Blackwell.

Leach, M., \& Scoones, I. (Eds.). (2015). Carbon conflicts and forest landscapes in Africa. London, England: Taylor \& Francis Group.

Leichenko, R. M., \& Solecki, W. D. (2005). Exporting the American dream: Globalization and the creation of consumption landscapes in less developed country cities. Regional Studies, 39, 241-253.

Liu, J., Daily, G. C., Ehrlich, P. R., \& Luck, G. W. (2003). Effects of household dynamics on resource consumption and biodiversity. Nature, 421, 530-533.

Liu, Z., Ma, J., \& Chai, Y. (2017). Neighborhood-scale urban form, travel behavior and $\mathrm{CO}_{2}$ emissions in Beijing: Implications for low-carbon urban planning. Urban Geography, 38(3), 381-400.

Longhofer, W., \& Jorgenson, A. (2017). Decoupling reconsidered: Does world society integration influence the relationship between the environment and economic development? Social Science Research, 65, 17-29.

Longhofer, W., \& Schofer, E. (2010). National and global origins of environmental association. American Sociological Review, 71(4), 505-533.

Loo, B. P. Y., \& Banister, D. (2016). Decoupling transport from economic growth: Extending the debate to include environmental and social externalities. Journal of Transport Geography, 57, 134-144.

Luque, A., Edwards, G., \& Lalande, C. (2013). The local governance of climate change: New tools to respond to old limitations in Esmeraldas, Ecuador. Local Environment, 18(6), 738-751.

Marcotullio, P. J., Hughes, S., Sarzynski, A., Pincetl, S., Sanchez Pena, L., Romero-Lankao, P., ... Seto, K. C. (2014). Urbanization and the carbon cycle: Contributions from social science. Earth's Future, 2(10), 496-514.

Marselis, S., Feng, K., Liu, Y., Teodoro, J. D., \& Hubacek, K. (2017). Agricultural land displacement and undernourishment. Journal of Cleaner Production, 161, 619-628.

Mayer, A. (2017). Democratic institutions and the energy intensity of well-being: A cross-national study. Energy, Sustainability and Society, 7, 36.

Mazur, A., \& Rosa, E. (1974). Energy and life-style: Massive energy consumption may not be necessary to maintain current living standards in America. Science, 186 , 607-610.

McCay, B. J., \& Acheson, J. M. (Eds.). (1987). The question of the commons. The culture and ecology of communal resources. Tucson: University of Arizona Press.

McCollum, D., \& Yang, C. (2009). Achieving deep reductions in US transport greenhouse gas emissions: Scenario analysis and policy implications. Energy Policy, 37(12), 5580-5596.

McGee, J., Ergas, C., Greiner, P., \& Clement, M. (2017). How do slums change the relationship between urbanization and the carbon intensity of well-being? PLoS ONE, 12(12), e0189024.

McGuirk, P. M., Bulkeley, H., \& Dowling, R. (2016). Configuring urban carbon governance: Insights from Sydney, Australia. Annals of the American Association of Geographers, 106, 145-166.

Meyer, J. W., Boli, J., Thomas, G., \& Ramirez, F. O. (1997). World society and the nation-state. American Journal of Sociology, 103, $144-181$.

Meyer, W. J., \& Crumley, C. L. (2011). Historical ecology: Using what works to cross the divide. In T. Moore \& L. Armada (Eds.), Atlantic Europe in the first millennium BC: Crossing the divide (pp. 109-134). Oxford, England: Oxford University Press. 
Mileva, A., Johnston, J., Nelson, J. H., \& Kammen, D. M. (2016). Power system balancing for deep decarbonization of the electricity sector. Applied Energy, 162, 1001-1009.

Miller Hesed, C. D., \& Paolisso, M. (2015). Cultural knowledge and local vulnerability in African American communities. Nature Climate Change, 5, 683-687.

Mol, A. (2003). Globalization and environmental reform: The ecological modernization of the global economy. Cambridge: MIT Press.

Mol, A., Spaargaren, G., \& Sonnenfeld, D. (2014). Ecological modernization theory: taking stock, moving forward). In S. Lockie, D. Sonnenfeld, \& D. Fisher (Eds.), The Routledge international handbook of social and environmental change (pp. 15-30). New York, NY: Routledge.

Moran, E. (2016). Roads and dams: Infrastructure-driven transformations in the Brazilian Amazon. Ambiente \& Sociedade, 19(2), 207-220.

Nel, A. (2015). The neoliberalisation of forestry governance, market environmentalism and re-territorialisation in Uganda. Third World Quarterly, 36(12), 2294-2315.

Nel, A. (2017). Carbon forestry and forestry governance. In S. Paladino \& S. J. Fiske (Eds.), The carbon fix: Forest carbon, social justice, and environmental governance (pp. 302-320). London, England: Routledge/Taylor \& Francis Group.

Nelson, M. C., Ingram, S. E., Dugmore, A. J., Streeter, R., Peeples, M. A., McGovern, T. H., ... Smiarowski, K. (2016). Climate challenges, vulnerabilities, and food security. Proceedings of the National Academy of Sciences, 113(2), 298-303.

Oberthür, S. (2016). Reflections on global climate politics post Paris. The International Spectator, 51, 80-94.

OECD (Organisation for Economic Co-operation and Development). (2002). Indicators to measure decoupling of environmental pressure from economic growth. Paris, France: OECD.

Olson, R. (2002). Shifting baselines: Slow-motion disaster in the sea. ActionBioscience. Retrieved from http://www.actionbioscience.org/environment/olson. html\#primer

Ostrom, E. (2014). A polycentric approach for coping with climate change. Annals of Economics and Finance, 15(1), 71-108.

Paladino, S., \& Fiske, S. J. (Eds.). (2017). The carbon fix: Forest carbon, social justice, and environmental governance. London, England: Routledge/Taylor \& Francis Group.

Paltsev, S., Reilly, J. M., Jacoby, H. D., \& Morris, J. F. (2009). The cost of climate policy in the United States. Energy Economics, 31, S235-S243.

Parks, B., \& Roberts, T. (2010). Climate change, social theory and justice. Theory, Culture and Society, 27(2-3), 134-166.

Pauly, D. (1995). Anecdotes and the shifting baseline syndrome of fisheries. Trends in Ecology \& Evolution, 10, 430.

Peters, G., Weber, C. L., Guan, D., \& Hubacek, K. (2007). China's growing $\mathrm{CO}_{2}$ emissions: A race between lifestyle changes and efficiency gains. Environmental Science and Technology, 41, 5939-5944. https://doi.org/10.1021/es070108f

Pinkerton, E. (Ed.). (2011). Co-operative management of local fisheries: New directions for improved management and community development. Vancouver, Canada: University of British Columbia Press.

Poffenberger, M. (2017). Empowering forest dependent communities: The role of REDD+ and PES projects. In S. Paladino \& S. J. Fiske (Eds.), The carbon fix: Forest carbon, social justice, and environmental governance (pp. 273-285). London, England: Routledge.

Prell, C., \& Feng, K. (2016). Unequal carbon exchanges: The environmental and economic impacts of iconic U.S. consumption items. Journal of Industrial Ecology, 20(3), 537-546. https://doi.org/10.1111/jiec.12377

Prell, C., Feng, K., Sun, L., Geores, M., \& Hubacek, K. (2014). Economic gains and environmental losses of US consumption: A world-systems and input-output approach. Social Forces, 93, 405-428.

Prell, C., Sun, L., Feng, K., \& Myroniuk, T. W. (2015). Inequalities in global trade: A cross-country comparison of trade network position, economic wealth, pollution and mortality. PLOS ONE, 10(12), e0144453. https://doi.org/10.1371/journal.pone.0144453

Rabe, B. (2007). Environmental policy and the bush era: The collision between the administrative presidency and state experimentation. Publius: The Journal of Federalism, 37, 413-431.

Redman, C. (1999). Human impacts on ancient environments. Tucson: University of Arizona Press.

Resilience Alliance. (2010). Assessing resilience in social-ecological systems: Workbook for practitioners. Version 2.0. Retrieved from http://www.resalliance. org/3871.php

Riahi, K., Gruebler, A., \& Nakicenovic, N. (2007). Scenarios of long-term socio-economic and environmental development under climate stabilization. Technological Forecasting and Social Change, 74(7), 887-935.

Richter, B. D., Postel, S., revenga, C., Scudder, T., Lehner, B., Churchill, A., \& Chow, M. (2010). Lost in development's shadow: The downstream human consequence of dams. Water Alternatives, 3(2), 14-42.

Rick, T. C., \& Lockwood, R. (2013). Integrating paleobiology, archaeology, and history to inform biological conservation. Conservation Biology, $27,45-54$.

Risky Business Project. (2016). From risk to return: Investing in a clean energy economy. Retrieved from https://riskybusiness.org/site/assets/uploads/RiskyBusiness_ FromRiskToReturn.pdf

Roberts, T., \& Parks, T. (2007). A climate of injustice: Global inequality, north-south politics, and climate policy. Cambridge: MIT Press.

Romero-Lankao, P., Gurney, K. R., Seto, K. C., Chester, M., Duren, R. M., Hughes, S., .. Stokes, E. (2014). A critical knowledge pathway to low-carbon, sustainable futures: Integrated understanding of urbanization, urban areas, and carbon. Earth's Future, 2(10), 515-532.

Rosa, E., \& Dietz, T. (2012). Human drivers of national greenhouse gas emissions. Nature Climate Change, 2, 581-586.

Rosa, E., Rudel, T., York, R., Jorgenson, A., \& Dietz, T. (2015). The human (anthropogenic) driving forces of global climate change. In R. Dunlap \& R. Brulle (Eds.), Climate change and society: Sociological perspectives (pp. 32-60). Oxford, England: Oxford University Press.

Rosa, E., York, R., \& Dietz, T. (2004). Tracking the anthropogenic drivers of ecological impacts. Ambio, 33(8), 509-512.

Rosenzweig, C., Solecki, W., Romeo-Lankao, P., Mehrotra, S., Dhakal, S., \& Ali-Ibrahim, S. (Eds.). (2018). Second assessment of research on climate change in cities. Cambridge, UK: Cambridge University Press.

Ruddiman, W. F. (2005). How did humans first alter climate? Scientific American, 292, 46-53.

Ruddiman, W. F., \& Ellis, E. (2009). Effect of per-capita land use changes on Holocene forest clearance and CO2 emissions. Quaternary Science Reviews, 28, 3011-3015.

Rudel, T. (2005). Tropical forests: Regional paths of destruction and regeneration in the late twentieth century. New York, NY: Columbia University Press.

Rudel, T. (2009). How do people transform landscapes? A sociological perspective on suburban sprawl and tropical deforestation. American Journal of Sociology, 115, 129-154.

Schnaiberg, A. (1980). The environment: From surplus to scarcity. New York, NY: Oxford.

Schofer, E., \& Hironaka, A. (2005). The effects of world society on environmental protection outcomes. Social Forces, 84(1), $25-47$.

Schor, J. B. (1998). The overspent American: Upscaling, downshifting and the new consumer. New York, NY: Basic Books.

Schor, J. B. (2005). Sustainable consumption and worktime reduction. Journal of Industrial Ecology, 9(1), 37-50.

Seto, K. C., Solecki, W. D., \& Griffith, C. A. (Eds.). (2016). The Routledge handbook of urbanization and global environmental change. New York, NY: Routledge.

Shandra, J., London, B., Whooley, O., \& Williamson, J. (2004). International nongovernmental organizations and carbon dioxide emissions in the developing world: A quantitative, cross-national analysis. Sociological Inquiry, 74, 520-544.

Shen, L., \& Sun, L. (2016). Review on carbon emissions, energy consumption and low-carbon economy in China from a perspective of global climate change. Journal of Geographical Sciences, 26(7), 855-870. 
Shove, E., Pantzar, M., \& Watson, M. (2012). The dynamics of social practice: Everyday life and how it changes. London, NY: Sage.

Shwom, R. (2011). A middle range theorization of energy politics: The struggle for energy efficient appliances. Environmental Politics, $20,705-726$.

Shwom, R., \& Lorenzen, J. (2012). Changing household consumption to address climate change: Social scientific insights and challenges. WIREs Climate Change, 3, $379-395$.

Smil, V. (2010). Energy transitions: History, requirements, prospects. Santa Barbara, CA: ABC-CLIO.

Smith, B., \& Zeder, M. (2013). The onset of the Anthropocene. Anthropocene, 4, 8-13.

Smith, P., Bustamante, M., Ahammad, M., Clark, H., Dong, H., Elsiddig, E. A., ... Tubiello, F. (2014). Agriculture, forestry and other land use (AFOLU). In O. Edenhofer, R. Pichs-Madruga, Y. Sokona, E. Farahani, S. Kadner, K. Seyboth, A. Adler, I. Baum, S. Brunner, P. Eickemeier, B. Kriemann, J. Savolainen, S. Schlömer, C. von Stechow, T. Zwickel, \& J. C. Minx (Eds.), Climate change 2014: Mitigation of climate change. Contribution of working group III to the fifth assessment report of the intergovernmental panel on climate change. Cambridge, England: Cambridge University Press.

Solecki, W., Rosenzweig, C., Dhakal, S., Roberts, D., Salisu Barau, A., Schultz, S. \& Ürge-Vorsatz, D. (2018). City transformations in a 1.5 C warmer world. Nature Climate Change, 8, 177-181.

Spreng, C., Sovacool, B., \& Spreng, D. (2016). All hands on deck: Polycentric governance for climate change insurance. Climatic Change, 139, 129-140.

Stern, P., Sovacool, B., \& Dietz, T. (2016). Towards a science of climate and energy choices. Nature Climate Change, 6, 547-555.

Strauss, S., Rupp, S., \& Love, T. (2013). Introduction. Powerlines: Cultures of energy in the twenty-first century. In S. Strauss, S. Rupp, \& T. Love (Eds.), Cultures of energy: Power, practices, technologies (pp. 10-39). Walnut Creek, CA: Left Coast Press.

Streeter, R., Dugmore, A., Lawson, I., Erlendsson, E., \& Edwards, K. (2015). The onset of the palaeoanthropocene in Iceland: Changes in complex natural systems. The Holocene, 25(10), 1662-1675.

Thombs, R. (2017). The paradoxical relationship between renewable energy and economic growth: A cross-national panel study, 1990-2013. Journal of World-Systems Research, 23(2), 540-564.

Thombs, R. (2018a). The transnational tilt of the treadmill and the role of trade openness on carbon emissions: A comparative international study, 1965-2010. Sociological Forum, 33(2), 422-442.

Thombs, R. (2018b). Has the relationship between non-fossil fuel energy sources and $\mathrm{CO}_{2}$ emissions changed over time? A cross-national study, 2000-2013. Climatic Change, 148(4), 481-490.

Tilly, C. (1992). Coercion, capital, and European states, AD 990-1992. Cambridge, England: Blackwell.

Turner, B. L., II, Moss, R. H., \& Skole, D. L. (1993). Relating land use and global land-cover change: A proposal for an IGBP-HDP core project (GBP Report No. 24. HDP Report No. 5). Stockholm, Sweden: International Geosphere-Biosphere Programme.

Urry, J. (2016). Complex systems and multiple crises of energy. In S. A. Crate \& M. Nuttall (Eds.), Anthropology and climate change: From actions to transformations (pp. 105-120). London, England: Routledge.

USGCRP. (2017). In D. J. Wuebbles, D. W. Fahey, K. A. Hibbard, D. J. Dokken, B. C. Stewart, \& T. K. Maycock (Eds.), Climate science special report: Fourth national climate assessment (Vol. I, p. 470). Washington, DC: U.S. Global Change Research Program.

Veblen, T. (1934). Theory of the leisure class. New York, NY: Modern Library.

Victor, D., Akimoto, K., Kaya, Y., Yamaguchi, M., Cullenward, D., \& Hepburn, C. (2017). Prove Paris was more than paper promises. Nature News, $548(7665)$, 25.

Walker, R. T., Moran, E. F., \& Anselin, L. (2000). Deforestation and cattle ranching in the Brazilian Amazon: External capital and household processes. World Development, 28(4), 683-699.

Weber, C., \& Matthews, H. (2008). Quantifying the global and distributional aspects of American household carbon footprint. Ecological Economics, 66(2), 379-391.

White, L. A. (2016). Modern capitalist culture. New York, NY: Routledge.

Wilk, R. (2010). Consumption embedded in culture and language: Implications for finding sustainability. Sustainability: Science, Practice and Policy, 6(2), 1-11.

Williams, B. (2001). A river runs through us. American Anthropologist, 103(2), 409-431.

Yao, C., Feng, K., \& Hubacek, K. (2015). Driving forces of CO2 emissions among G20 countries: An index decomposition analysis from 1971 to 2010. Ecological Informatics, 23, 93-100.

York, R. (2007). Demographic trends and energy consumption in European Union nations, 1960-2025. Social Science Research, 36(3), 855-872.

York, R. (2008). De-carbonization in former soviet republics, 1992-2000: The ecological consequences of de-modernization. Social Problems, 55(3), 370-390.

York, R. (2012a). Asymmetric effects of economic growth and decline on $\mathrm{CO}_{2}$ emissions. Nature Climate Change, 2, $762-764$.

York, R. (2012b). Do alternative energy sources displace fossil fuels? Nature Climate Change, 2(6), 441-443.

York, R. (2016). Decarbonizing the energy supply may increase energy demand. Sociology of Development, 2(3), $265-273$.

York, R. (2017). Why petroleum did not save the whales. Socius: Sociological Research for a Dynamic World, 3. https://doi.org/10.1177/2378023117739217

York, R., \& Light, R. (2017). Directional asymmetry in sociological analyses. Socius: Sociological Research for a Dynamic World, 3. https://doi.org/ $10.1177 / 2378023117697180$

York, R., \& McGee, J. (2016). Understanding the Jevons paradox. Environmental Sociology, 2(1), 77-87.

York, R., \& McGee, J. (2017). Does renewable energy development decouple economic growth from $\mathrm{CO}_{2} \mathrm{emissions}$ Socius: Sociological Research for a Dynamic World, 3. https://doi.org/10.1177/2378023116689098

York, R., \& Rosa, E. (2012). Choking on modernity: A human ecology of air pollution. Social Problems, 59(2), 282-300.

York, R., Rosa, E., \& Dietz, T. (2003). STIRPAT, IPAT and ImPACT: Analytic tools for unpacking the driving forces of environmental impacts. Ecological Economics, $46(3), 351-365$.

How to cite this article: Jorgenson AK, Fiske S, Hubacek K, et al. Social science perspectives on drivers of and responses to global climate change. WIREs Clim Change. 2019;10:e554. https://doi.org/10.1002/wcc.554 